$\mathrm{A} \int_{\cos } \mathrm{H}$

Article history :

Received : 10.12.2014

Accepted : 21.05.2015
A CASE STUDY

THEASIAN JOURNALOF HORTICULTURE

Volume 10 | Issue 1 | June, 2015 | 167-172

Visit us -www.researchjournal.co.in

\section{Returns analysis of technology of paclobutrazol application in rainfed Alphonso mango production in Maharashtra}

\section{J.M. TALATHI, V.G. NAIK ${ }^{1}$ AND D.B. MALAVE ${ }^{1}$}

Members of the Research Forum

Associated Authors:

${ }^{1}$ Department of Agricultural

Economics, Dr. B.S. Konkan Krishi

Vidyapeeth, Dapoli, RATNAGIRI

(M.S.) INDIA

Author for correspondence :

J.M. TALATHI

Department of Agricultural

Economics, Dr. B.S. Konkan Krishi

Vidyapeeth, Dapoli, RATNAGIRI

(M.S.) INDIA

Email : hodecon@ rediffmail.com
ABSTRACT : The Paclobutrozol (PBZ) application has induced early flowering in rainfed mango orchard due to enhanced use of critical inputs as a per canopy of mango tree. The application of manures and fertilizers viz., N.P.K. when compared with recommended levels. The analysis revealed that the input gap for manures was to the extent of 78.5 per cent in PBZ non-adopter group and 74.7 per cent in PBZ adopter group. In case of chemical fertilizer viz., N.P.K. was to the extent of 58.67 per cent, 34 per cent and 59 per cent in PBZ non-adopter group and 9.33 per cent, 14 per cent and 46 per cent in PBZ adopters group, respectively. On account of this, the per hectare productivity of rainfed mango orchard was 6.2 t/ha in PBZ adopter category and 3.9 t/ha in PBZ non-adopter category. The per hectare cost of cultivation was Rs. 122373/- and Rs. 69561/- with per tone cost of cultivation of mango was to the tune of Rs. 26037/- and Rs. 23822/ - in PBZ adopter and PBZ non-adopter category, respectively. The per hectare gross returns were Rs. 251450/- and Rs. 119720/- with benefit cost ratio of 2.05 and 1.72 in PBZ in the same order. The benefits due to PBZ, application were valued to Rs. 95230/ha with a additional cost of Rs. 27730/ha realizing net incremental benefits to the tune of Rs. 67460/ha. Better productivity and price advantage grabbed in the early start of marketing season, were the benefits to the PBZ adopter category which resulted into higher per hectare income. As a whole, the net returns were 157.33 per cent higher for PBZ adopters than to PBZ non-adopters.

KEY WORDS : Paclobutrozol, Adopters, Non-adopters, Incremental benefits

HOW TO CITE THIS ARTICLE : Talathi, J.M., Naik, V.G. and Malave, D.B. (2015). Returns analysis of technology of paclobutrazol application in rainfed Alphonso mango production in Maharashtra. Asian J. Hort., 10(1) : 167-172. 